\title{
Experimental wound healing using microamperage electrical stimulation in rabbits
}

\author{
Mohammad Bayat, PhD; ${ }^{*}$ Zahra Asgari-Moghadam, BSc; ${ }^{2}$ Mohammad Maroufi, PhD; ${ }^{3}$ Fatemeh-Sadat \\ Rezaie, BSc; ${ }^{4}$ Maryam Bayat, MD; ${ }^{5}$ Mohammad Rakhshan, MD $^{6}$ \\ ${ }^{1}$ Cell and Molecular Biology Research Center and Departments of Anatomy, ${ }^{2}$ Physiotherapy, Shaheed Beheshti Uni- \\ versity of Medical Sciences, Tehran, Iran (Islamic Republic of); ${ }^{3}$ Department of Physiotherapy, Iran University of \\ Medical Sciences, Tehran, Iran (Islamic Republic of); ${ }^{4}$ Royal Institute, Tehran, Iran (Islamic Republic of); ${ }^{5}$ Islamic \\ Azad University, Tehran, Iran (Islamic Republic of); ${ }^{6}$ Department of Pathology, Shaheed Beheshti University of Medi- \\ cal Sciences, Tehran, Iran (Islamic Republic of)
}

\begin{abstract}
We investigated the effects of microamperage electrical stimulation (MES) on the healing of skin incision in rabbits. Thirty male adult rabbits were randomly divided into sham-treated and experimental groups. Each group was divided into three subgroups, based on the duration of experiment (4, 7, and 15 days). A full-thickness incision was made on the skin of each rabbit. The experimental group received an MES of 200 microamperes current intensity for $2 \mathrm{~h} /$ day. Morphometrical and biomechanical evaluations were carried out. The mean number of fibroblasts at day 7 and the mean of tensile strength at day 15 were found to be significantly higher for the experimental group than for those in the sham-treated group ( $p<0.01$ and $p<0.05$, respectively). Daily application of MES significantly accelerated the wound-healing process of full-thickness incision in the rabbits' skin.
\end{abstract}

Key words: biomechanical evaluation, electrotherapy, fibroblast, histology, microamperage current, morphometry, rabbits, skin incision, tensile strength, wound healing.

\section{INTRODUCTION}

Wound healing, the result of a complex tissue repairing process, is a continuing challenge in rehabilitation medicine. Despite some recent advances in understand- ing its basic principles, problems in wound healing continue to cause significant morbidity and mortality [1].

Living tissues possess direct-current electropotentials that appear to regulate, at least partly, the healing process. Following tissue injury, a current of injury is generated that is thought to trigger biological repair [2]. Exogenous electrical stimuli have been shown to enhance the healing of wounds in both human subjects and animal models [37]. In recent years, electrical stimulation of very low amplitude and frequency modulation has become an increasingly popular treatment modality [8]. This form of stimulation has been referred to as microamperage electrical stimulation (MES). MES is defined as stimulations with a very low frequency ( $1 \mathrm{~Hz}$ or less) and low intensity or amplitude $(1-1,000 \mu \mathrm{A})$ [9].

Substantial evidence exists that MES applied throughout the day significantly accelerates bone healing [10-13]; nonetheless, the evidence that MES predictably accelerates

\footnotetext{
Abbreviation: $\mathrm{MES}$ = microamperage electrical stimulation.

*Address all correspondence to Mohammad Bayat, PhD; Cell and Molecular Biology Research Center and Department of Anatomy, Medical Faculty of Shaheed Beheshti University of Medical Sciences, PO Box 19395/4719, Evin, Tehran, Iran; +98-21-2240-0681; fax: +98-21-2240-0681.
}

Email: bayat m@yahoo.com

DOI: 10.1682/JRRD.2005.05.0089 
dermal repair is less convincing [8,14-16]. In view of the recent scientific understanding of the wound-healing process, one would expect a beneficial outcome from an electrotherapy that decreases edema, attracts neutrophils and macrophages, stimulates growth of fibroblasts and granulation tissue, induces epidermal cell migration, inhibits bacteria [17], decrease the ulcer size [18], and accelerates healing time [3] in patients. Despite the theoretical basis for using MES to treat cutaneous wounds, not only have no controlled, experimental studies been conducted to demonstrate its effectiveness, but also no stimulation variables used have yet been established. We undertook this study in light of the growing enthusiasm for MES and the paucity of supporting evidence for its use.

Our null hypotheses were (1) the wounds of electrically stimulated animals would not show a significant change in neutrophils, fibroblasts, and blood vessel sections over time in comparison with the wounds of sham-treated group, which has received no treatment; and (2) no significant change in tensile strength would be seen in electrically stimulated animals compared with the sham-treated ones.

\section{METHODS}

In this investigation, we studied 30 male adult white Dutch rabbits, weighing a mean of 1,900 \pm 270 g standard deviation, all 4 to 6 months old. They were kept in individual cages with access to food and water. All the procedures were approved by the Medical Ethics Committee of Iran University of Medical Sciences.

On day zero, each rabbit was anesthetized by $50 \mathrm{mg} /$ $\mathrm{kg}$ ketamine hydrochloride, intramuscularly injected, along with $5 \mathrm{mg} / \mathrm{kg}$ diazepam. The dorsal hair of the rabbits was shaved and cleaned with povidone iodine. Under sterile conditions, we made a $3 \mathrm{~cm}$ full-thickness skin incision, including panniculus carnosus. We sutured the incision, located distal to the right scapula, using two interrupted 3/0 silk sutures so that the distance between the two edges of the incision was kept constant at $3 \mathrm{~mm}$ in all the rabbits. The animals were randomly divided into sham-treated $(n=15)$ and experimental $(n=15)$ groups.

\section{Experimental Group}

Treatment was started $24 \mathrm{~h}$ after surgery. We used a Micro Plus $^{\mathrm{TM}}$ (Biomedical Life Systems, Vista, California) electrostimulation treatment device. Carbon rubberized (BioDerm $^{\mathrm{TM}}$, Biomedical Life Systems, Vista, California) electrodes were placed on sterile pads moistened with saline solution. Because we placed the active electrode on the incision, we placed the indifferent one on the shaved area $5 \mathrm{~cm}$ distal away from the wound. We applied MES with a 50 percent duty cycle, frequency of $0.5 \mathrm{~Hz}$, current intensity of $200 \mu \mathrm{A}$, and current density of $66 \mu \mathrm{A}$ continuously $2 \mathrm{~h}$ /day by negative polarity for the first 3 days. After that, we reversed the polarity of the active and indifferent electrodes. The size of electrode changed the current density; as we decreased the size of the active electrode, the current density beneath the smaller electrode increased and had more localized effects. The larger the electrode, the larger the area over which the current was spread, decreasing the current density [9,19-20]. We therefore chose the surface areas of the active and indifferent electrodes to be $3 \mathrm{~cm}^{2}$ and $16 \mathrm{~cm}^{2}$, respectively (Figure 1).

\section{Sham-Treated Group}

We applied the same procedure here as we did the experimental group, but with no current.

The rabbits in each group were divided into three equal subgroups (A $[n=5], \mathrm{B}[n=5]$, and C $[n=5]$ ). Electrotherapy lasted 3 days (3 sessions) in subgroup A, 6 days (6 sessions) in subgroup B, and 14 days (14 sessions) in subgroup $C$. The rabbits of subgroups $A, B$, and $\mathrm{C}$ were killed by chloroform on days 4, 7, and 15 after surgery, respectively.

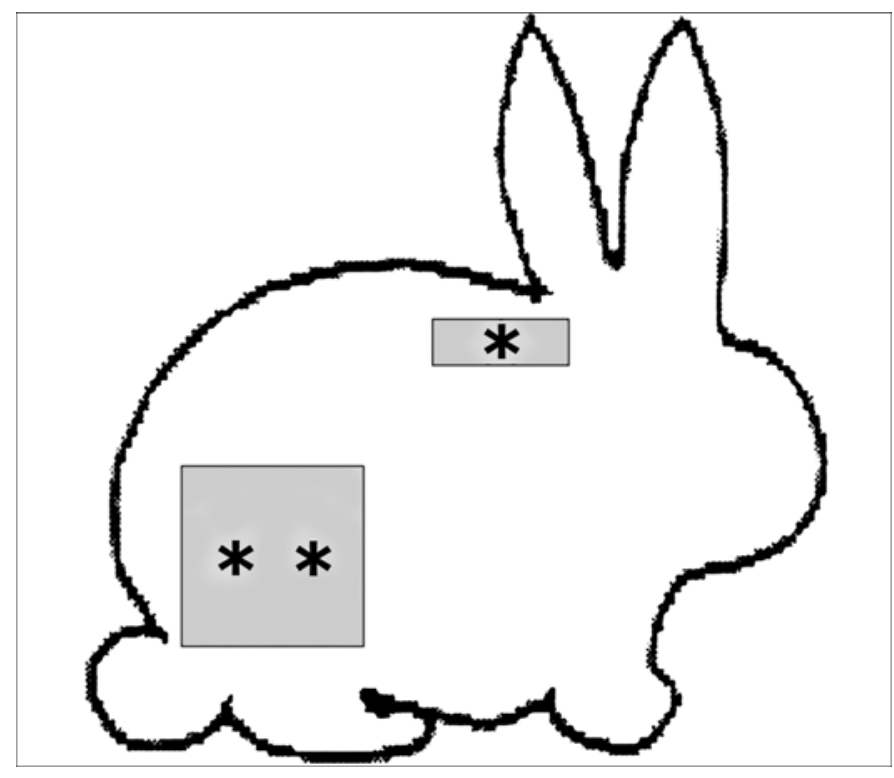

Figure 1.

Diagram of position of active $(*)$ and indifferent $(* *)$ electrodes. 


\section{Histological Examinations}

We excised the first sample for histological examinations from the wound bed and normal adjacent skin, fixed it in formaldehyde saline, and embedded it in paraffin blocks. Sagittal sections were cut and stained with hematoxylin and eosin. In order for fibroblasts, neutrophils, and blood vessel sections to be counted, we examined 10 zones from the sample morphometrically through a calibrated ocular on a Nikon light microscope (Nikon, Tokyo, Japan) at a magnification of $400 \times$. We performed histological examinations in a double-blind fashion and in accordance with a procedure reported by Young and Dyson [21], albeit with some modifications.

\section{Biomechanical Examinations}

After each animal had been killed, we removed the skin with the wound. We cut standardized $5 \mathrm{~mm}$-wide skin strips perpendicularly to the incisions with a doubleblade cutting instrument. The specimens were then placed in 0.9 percent saline. We began taking measurements within $1 \mathrm{~h}$ postnecropsy. From each wound, we obtained one strip specimen. We mounted the specimens in a material testing machine (Zwick 1494, universal testing machine, Ulm, Germany) using two clamps with rough surfaces, with the wound in the middle of the free surface. The jaw space, i.e., the distance between the edges of the clamps, was $5 \mathrm{~mm}$.

Keeping the deformation rate constant at $15 \mathrm{~mm}$ a minute, we loaded the specimens uniaxially, so that failure and complete load-deformation curves were recorded by transducers coupled to bridges and sampled in a personal computer by an analog-to-digital converter. From these curves, we calculated load versus strain and stress versus strain and, from these data computed tensile strength. The tensile strength measurement was normalized by the gram tensile strength per square millimeter of the wounded (wound bed) tissue. Analyzed by Student's $t$-test, the data were presented as mean \pm standard error. A probability $(p)$ of $<0.05$ was considered significant.

\section{RESULTS}

None of the rabbits showed any sign of swelling or exudation at the surgical site. The results, obtained on the basis of morphometrical and biomechanical examinations are shown in Figures 2 to 5. Histological micrographs are shown in Figures 6 to 8. The mean number of neutrophils in the experimental group was lower than that

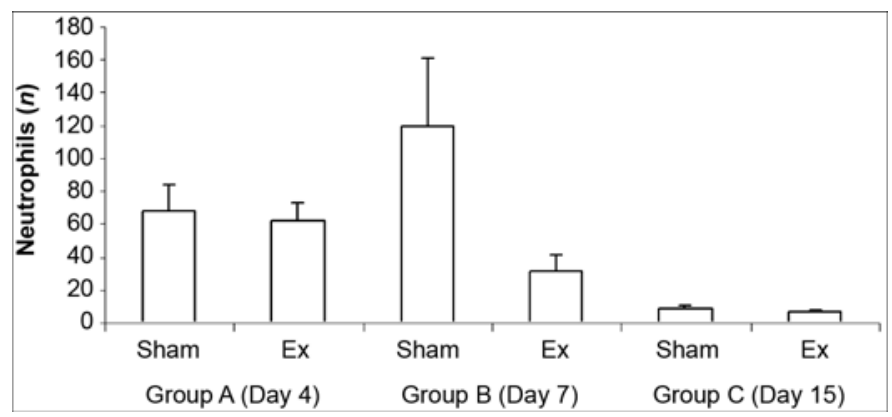

Figure 2.

Mean \pm standard error of neutrophils in ten zones of incisional wound bed in rabbits of sham-treated (Sham) $(n=15)$ and experimental (Ex) $(n=15)$ groups at sequential intervals.

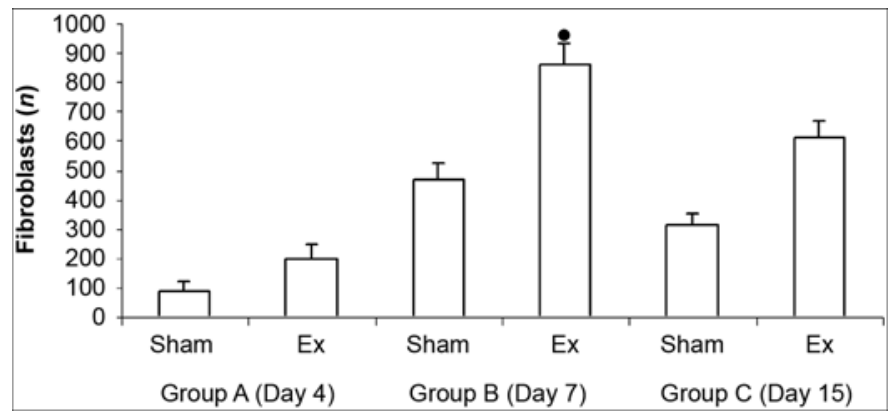

Figure 3.

Mean \pm standard error of fibroblasts in ten zones of incisional wound bed in rabbits of sham-treated (Sham) $(n=15)$ and experimental (Ex) $(n=15)$ groups at sequential intervals. Student $t$-test showed significant differences between sham-treated group and experimental group at day $7, p<0.01$.

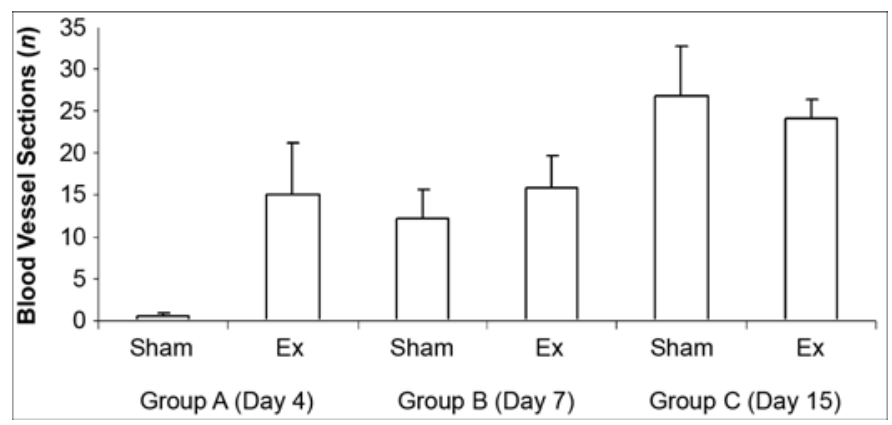

Figure 4.

Mean \pm standard error of blood vessel sections in ten zones of incisional wound bed in rabbits of sham-treated (Sham) $(n=15)$ and experimental (Ex) $(n=15)$ groups at sequential intervals. 
JRRD, Volume 43, Number 2, 2006

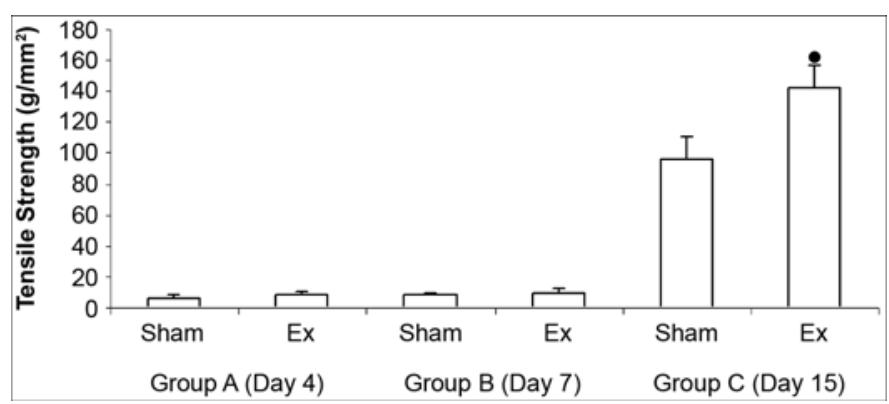

Figure 5.

Mean \pm standard error of tensile strength $\left(\mathrm{g} / \mathrm{mm}^{2}\right.$ ) of incisional wound bed in rabbits of sham-treated (Sham) $(n=15)$ and experimental (Ex) ( $n=15)$ groups at sequential intervals. Student $t$-test showed significant differences between sham-treated group and experimental group at day $15, p<0.05$.

in the sham-treated group throughout the study period; nevertheless, no significant differences were found between the groups.

\section{Day 4 After Surgery}

The mean number of fibroblasts and blood vessel sections, as well as the tensile strength of the experimental group, were higher than those of the sham-treated group. No significant differences were found in any of the parameters investigated between the studied groups.

\section{Day 7 After Surgery}

The mean number of fibroblasts and blood vessel sections, as well as the tensile strength of the experimental group, was higher than those of the sham-treated group. Only the mean number of fibroblasts in the experimental group increased significantly as a result of MES $(p<0.01)$.

\section{Day 15 After Surgery}

The mean number of fibroblasts in the experimental group was higher than that in the sham-treated group. The mean of tensile strength of the experimental group was significantly higher than that of the sham-treated group $(p<0.05)$.

\section{DISCUSSION}

Yarkony, having reviewed medical management of pressure ulcers, reported that although numerous studies have been published on the effects of electrical stimulation on wound healing process, many of them either had

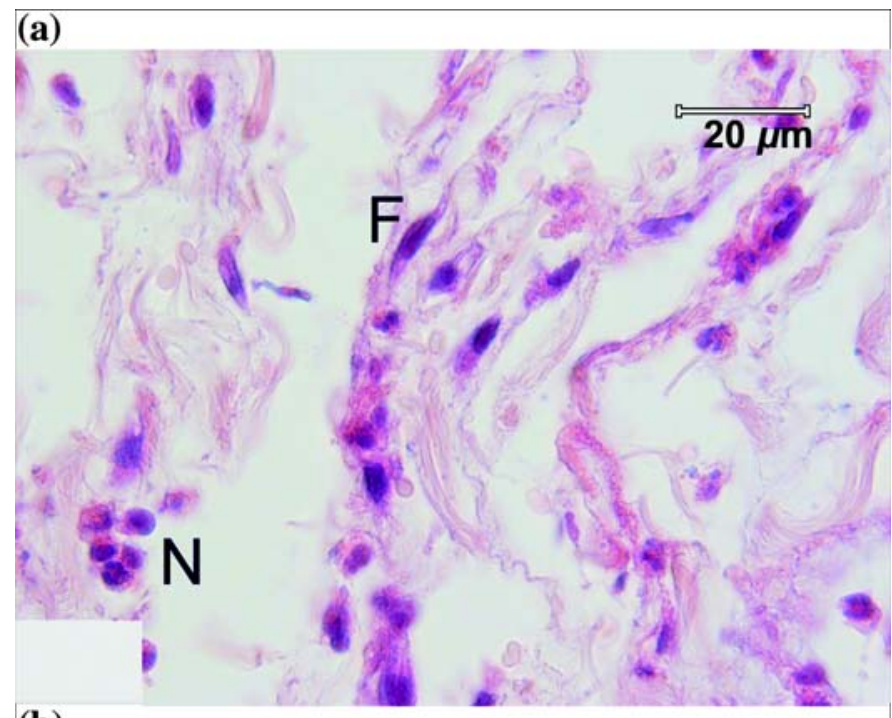

(b)

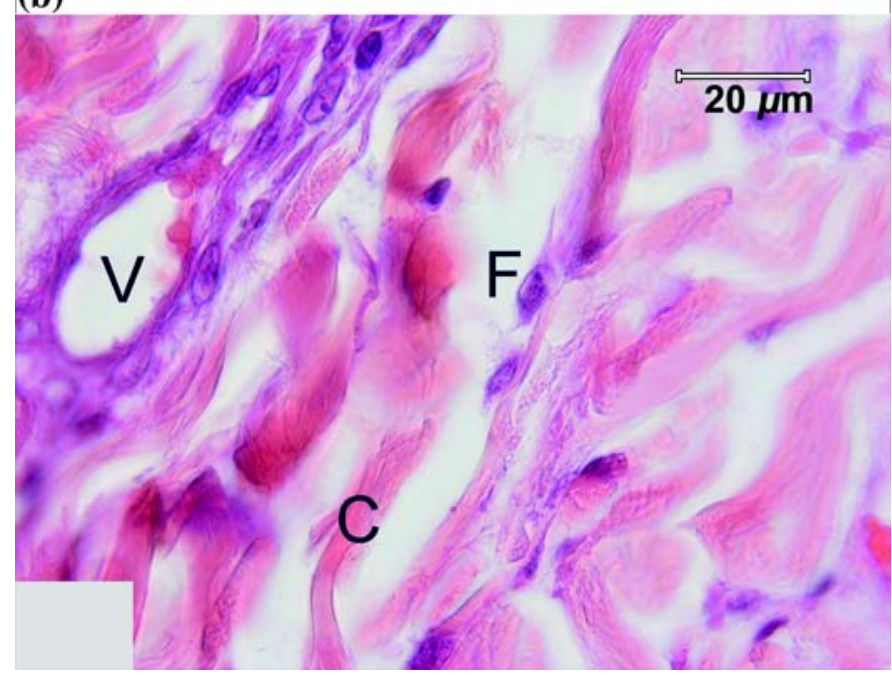

Figure 6.

Light micrographs $(100 \times)$ of incisional wound bed of (a) shamtreated $(n=5)$ and $(\mathbf{b})$ experimental group $(n=5) 4$ days after surgery. Marked connective tissue fibers shown experimental group compared with sham-treated group. $\mathrm{F}=$ fibroblast, $\mathrm{V}=$ blood vessel, $\mathrm{C}=$ connective tissue fiber, $\mathrm{N}=$ neutrophil.

a poor sample size or were poorly controlled [22]. Believing that the clinical use of electric stimulation techniques had not been established [17,22], Yarkony and Gentzkow called for further studies to determine the benefits and cost-effectiveness of electric stimulation $[17,22]$. This is lack of techniques for clinical use is particularly important because a therapist may be required to apply electric stimulation [22].

MES accelerated the wound-healing process of incisional wounds in rabbits in our study. In addition, a 
(a)

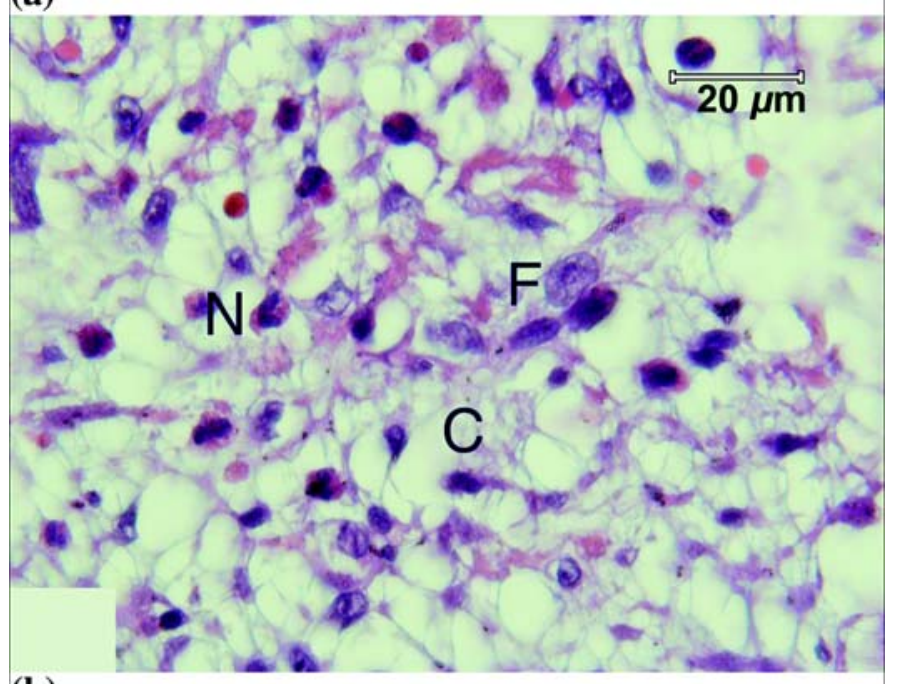

(b)

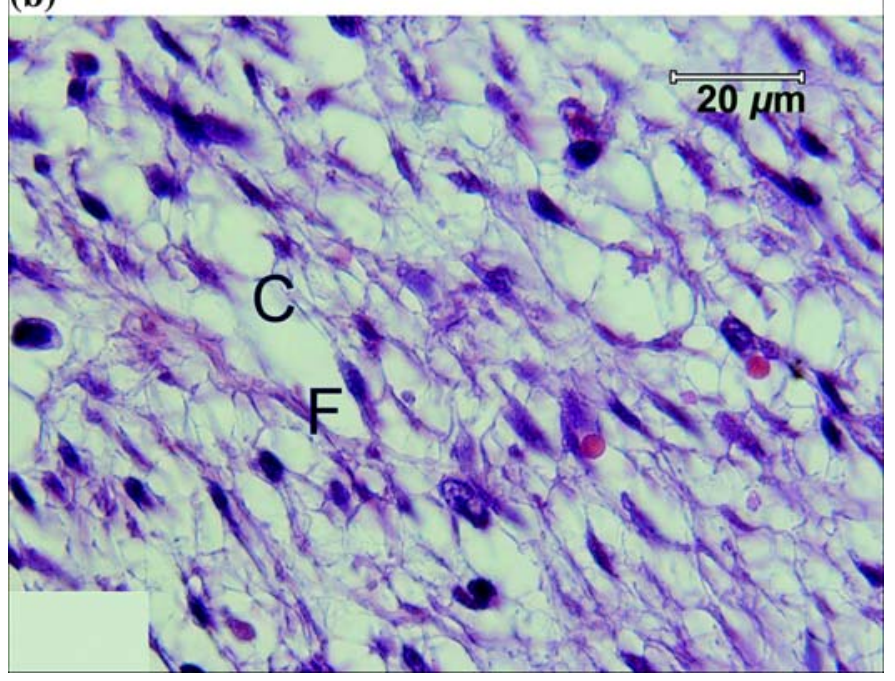

Figure 7.

Light micrographs $(100 \times)$ of incisional wound bed of (a) shamtreated $(n=5)$ and $(\mathbf{b})$ experimental group $(n=5) 7$ days after surgery. More fibroblasts shown in experimental group compared with sham-treated group. $\mathrm{F}=$ fibroblast, $\mathrm{C}=$ connective tissue fiber, $\mathrm{N}=$ neutrophil.

Student $t$-test rejected our null hypothesis. Therefore, MES, as performed in this study, increased fibroblast counts within 7 days and tensile strength within 15 days of the healing of surgically induced incisional lesions in rabbits.

To understand the mechanism of the effects of MES on the wound-healing process, one must analyze variables that might account for the observed outcome. Konikoff continuously delivered $10 \mu \mathrm{A}$ current for 7 days with a cathodal electrode to full-thickness $2 \mathrm{~cm}$ incisions. The

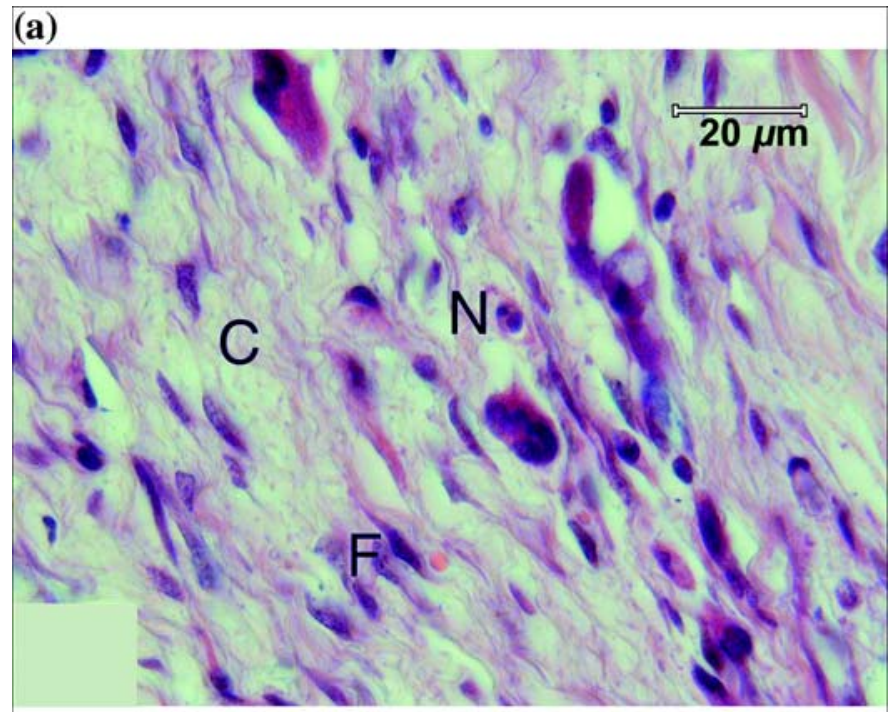

(b)

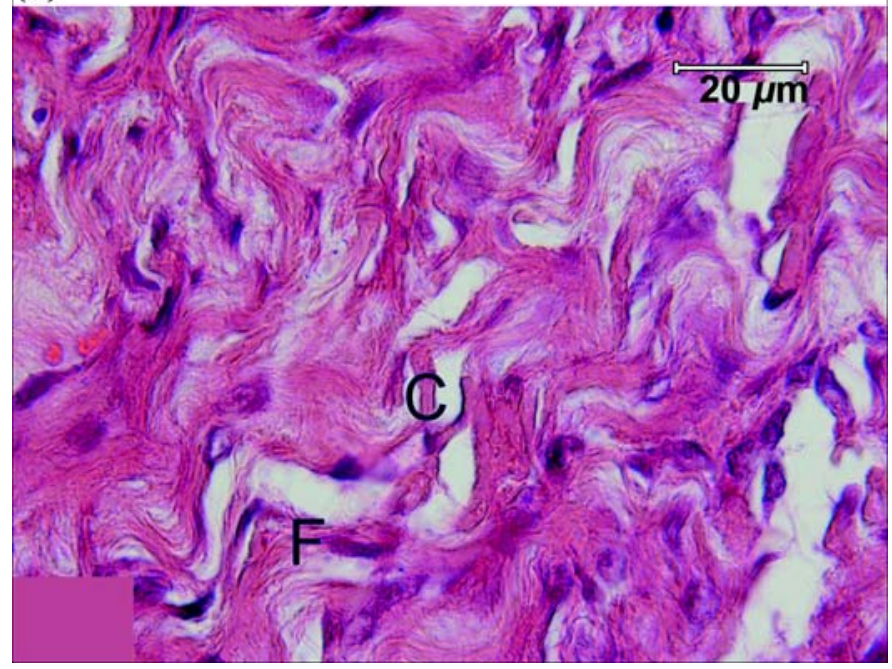

Figure 8.

Light micrographs (100 $\times$ ) of incisional wound bed of (a) sham-treated $(n=5)$ and (b) experimental group $(n=5) 15$ days after surgery. More connective tissue fibers and more mature fibroblasts shown in experimental group compared with sham-treated group. $\mathrm{F}=$ fibroblast, $\mathrm{C}=$ connective tissue fiber, $\mathrm{N}=$ neutrophil.

wounds were surgically induced on the skin of rabbit. The tensile strength was twice as high in treated wounds than that in the untreated wounds [14]. Canseven and Atalay examined the effects of direct microcurrents on collagen synthesis in wound healing on the third day of wounding in rabbit skin [15]. Two circular skin wounds were formed bilaterally on the gluteal region; one of the wounds was subjected to a current and the other was chosen as the control. The current intensities were 200 and $400 \mu \mathrm{A}$, and the application time was $8 \mathrm{~h} /$ day for 3 days. 
The hydroxyproline content was found to have increased in wound tissue at the end of $72 \mathrm{~h}$ of current application. The researchers concluded that collagen synthesis is promoted by electric current [15].

In the Leffmann et al. study, the wounds were treated $2 \mathrm{~h} /$ day with a $100 \mu \mathrm{A}$ current intensity, $0.3 \mathrm{~Hz}$ with a 50 percent duty cycle. Their results showed no significant differences between the MES-treated and control wounds in a change in wound size or any of the histological measurements [8].

In another study, Byl et al. treated surgically induced partial-thickness, full-thickness, and incisional wounds in Yucatan pigs with MES (100 $\mu \mathrm{A}, 1 \mathrm{~h} /$ day, 50\% duty cycle). No differences were found in tensile strength, collagen density, or visual appearance between the sham and treatment lesions [16]. Byl et al., having concluded that their study did not provide any evidence to support the use of MES to expedite wound healing in the Yucatan pig, stated that further studies were needed to determine whether a critical interaction exists between the size of the electrode and that of the wound, density of the current, duration of the treatment, polarity of treatment electrodes, acuity or chronicity of wounding, and effectiveness of microcurrent stimulation for wound healing [16]. Canseven and Atalay used a current intensity as high as ours $(200 \mu \mathrm{A})$; furthermore, their animal model and outcome were similar to those in our study [15]. Because the animal model, current intensity, and current density seem to be important factors in MES for enhancing wound healing, in the present study we chose a current intensity higher than those of the Leffmann et al. [8] and Byl et al. [16] studies.

The two following hypotheses may explain the positive effects of MES on wound healing. Cheng and colleagues, analyzing the biochemical effects occurring in the rat skin tissue during stimulation with MES, reported that 10 to $1,000 \mu \mathrm{A}$ direct current applied to skin strips $0.5 \mathrm{~cm}$ thick for $2 \mathrm{~h}$ in vitro increased the adenosine triphosphate concentration in the skin by five times [23]. Likewise, the administration of low-intensity (i.e., microamperage) current serves to boost the electromotive force behind the moving ions/radicals sufficient to allow entry into high-resistance zones of pathology (wound bed) [24] and allow favorable metabolism and repair to take place [25]. One can conclude that MES enhances healing by stimulating the circulatory system rather than the neural system.

We applied negative polarity to the wound for the first 3 days and positive polarity thereafter. The negative polarity (and its alkaline reaction) seems to inhibit the growth of bacteria [5-6,9].

We reversed the electrodes after the initial negativepole treatment. Gault and Gatens maintained that the positive pole promoted the migration of skin cells toward the center of the wound, thus decreasing its healing time [26]. Our results demonstrated that MES increased the number of fibroblasts at day 7 and tensile strength at day 15 compared with the sham-treated group.

As fibroblasts mature, they produce a matrix through which other cells can readily migrate and from which delicate new capillaries can obtain mechanical support [27]. On the other hand, during the proliferative phase of repair, fibroblasts of the granulation tissue develop into cells called "myofibroblasts," which are responsible for wound contraction [27-28].

Demir et al. made a $6 \mathrm{~cm}$ linear incision at the dorsal skin of rats [6]. In that study, Group 1 was given a constant direct current of $300 \mu \mathrm{A}$ for $30 \mathrm{~min} / \mathrm{d}$, and Group 2 was considered the control group. Electrical stimulation proved significantly effective in the inflammation, proliferation, and maturation phases of wound healing in their rats [6]. Demir et al. stated that a small amount of voltage, produced as long as the collagen bundle was subjected to stress, was necessary for the production, continuity, arrangement, and absorption of collagen. They suggested that the recorded current in experimental wounds triggered wound healing [6].

\section{CONCLUSIONS}

Having used MES in light of the aforementioned statements to accelerate wound healing and obtain a stronger scar, we conclude that the daily application of MES on surgically induced incisional wounds significantly accelerates the wound healing process in the rabbit skin. However, further investigations are required to address the stimulation effects in patients (or animals) suffering from conditions (e.g., diabetic mellitus) that seem to retard wound healing.

\section{ACKNOWLEDGMENTS}

Many thanks are due to the late Mrs. Jamileh Rezaie for her intellectual assistance. We would also like to thank Mr. Abasali Jafari-Nasb and Dr. Mohammad Reza 
Namavar for their editorial assistance and Jahade Daneshgahi of Iran University of Medical Sciences, Tehran, Iran (Islamic Republic of), for financial support.

This material is the result of work supported with resources and the use of facilities at the Iran University of Medical Sciences, Tehran, Iran (Islamic Republic of).

\section{REFERENCES}

1. Peacock EE, Cohen IK. Wound healing. In: McCarthy JG, May JW, Littler JW, editors. Plastic surgery. Vol 1. Philadelphia (PA): W.B. Saunders Company; 1990. p. 161-85.

2. Watson T. Electrical stimulation for wound healing. In: Bazin S, Kitchen S, editors. Clayton's electrotherapy. Philadelphia (PA): W.B. Saunders Company; 1994. p. 223-397.

3. Carley PJ, Wainapel SF. Electrotherapy for acceleration of wound healing: Low intensity direct current. Arch Phys Med Rehabil. 1985;66(7):443-46. [PMID: 3893385]

4. Brown M, McDonnel MK, Menton DN. Polarity effects on wound healing using electric stimulation in rabbits. Arch Phys Med Rehabil. 1989;70(8):624-27. [PMID: 2788400]

5. Taskan I, Ozyazgan I, Tercan M, Kardas Y, Balkanli S, Saraymen R, Zorlu U, Ozugul Y. A comparative study of the effect of ultrasound and electrostimulation on wound healing in rats. Plast Reconstr Surg. 1997;100(4):966-72. [PMID: 9290665]

6. Demir H, Balay H, Kirnap M. A comparative study of the effect of electrical stimulation and laser treatment on experimental wound healing in rats. J Rehabil Res Dev. 2004;41(2): 147-54. [PMID: 15558369]

7. Reger SI, Hyodo A, Negami S, Kambic HE, Sahgal V. Experimental wound healing with electrical stimulation. Artif Organs. 1999;23(5):460-62. [PMID: 10378943]

8. Leffmann DJ, Arnall DA, Holmgren PR, Cornwall MW. Effect of microamperage stimulation on the rate of wound healing in rats: A histological study. Phys Ther. 1994;74(3): 195-200. [PMID: 8115453]

9. Hooker DN. Electrical stimulation currents. In: Prentice WE, editor. Therapeutic modalities in sport medicine. St. Louis (MO): William C. Brown Company; 1994. p. 51-88.

10. Friedenberg ZB, Andrews T, Smolenski BI, Pearl BW, Brighton CT. Bone reaction to varying amounts of direct current. Surg Gynecol Obstet. 1970;131(5):894-99. [PMID: 5471542]

11. Friedenberg ZB, Robert PG Jr, Didizian NH, Brighton CT. Stimulation of fracture healing by direct current in the rabbit fibula. J Bone Joint Surg Am. 1971;53(7):1400-1408. [PMID: 5114702]
12. Goh JC, Bose K, Kang YK, Nugroho B. Effects of electrical stimulation on the biomechanical properties of fracture healing in rabbits. Clin Orthop Relat Res. 1988;(233):268-73. [PMID: 3261217]

13. Sharrard WJ. A double-blind trial of pulsed electromagnetic fields for delayed union of tibial fractures. J Bone Joint Surg Br. 1990;72(3):347-55. [PMID: 2187877]

14. Konikoff JJ. Electrical promotion of soft tissue repairs. Ann Biomed Eng. 1976;4(1):1-5. [PMID: 1084717]

15. Canseven AG, Atalay NS. Is it possible to trigger collagen synthesis by electric current in skin wounds. Indian J Biochem Biophys. 1996;33(3):223-27. [PMID: 8828294]

16. Byl NN, Mckenzie AL, West JM, Whitney JD, Hunt TK, Hopf HW, Scheuenstuht H. Pulsed microamperage stimulation: A controlled study of healing of surgically induced wounds in Yucatan pigs. Phys Ther. 1994;74(3):201-19. [PMID: 8115454] Erratum in: Phys Ther. 1994;74(6):595.

17. Gentzkow GD. Electrical stimulation to heal dermal wounds. J Dermatol Surg Oncol. 1993;19(8):753-58. [PMID: 8349916]

18. Griffin JW, Tooms RE, Mendius RA, Clifft JK, Vander Zwaag R, el-Zeky F. Efficacy of high voltage pulsed current for healing of pressure ulcers in patients with spinal cord injury. Phys Ther. 1991;71(6):433-42; discussion 442-44. [PMID: 2034707]

19. Cook TM. Instrumentation. In: Nelson RM, Currier D, editors. Clinical electrotherapy. Connecticut: Appleton and Lange; 1987. p. 11-26.

20. Brown M, Gogia PP, Sinacore DR, Menton DN. High-voltage galvanic stimulation on wound healing in guinea pigs: Longer-term effects. Arch Phys Med Rehabil. 1995;76(12): 1134-37. [PMID: 8540790]

21. Young SR, Dyson M. Effect of therapeutic ultrasound on the healing of full-thickness excised skin lesions. Ultrasonics. 1990;28(3):175-80. [PMID: 2339476]

22. Yarkony GM. Pressure ulcers: A review. Arch Phys Med Rehabil. 1994;75(8):908-17. [PMID: 8053799]

23. Cheng N, Van Hoof H, Bockx E, Hoogmartens MJ, Mulier JC, De Dijcker FJ, Sansen WM, De Loecker W. The effects of electric currents on ATP generation, protein synthesis, and membrane transport in rat skin. Clin Orthop Relat Res. 1982;(171):264-72. [PMID: 7140077]

24. Kahn J. Principles and practice of electrotherapy. Philadelphia (PA): Churchill Livingstone; 1987. p. 75-105.

25. Kloth LC, Feedar JA. Electrical stimulation in tissue repair. In: Kloth LC, Culloch MC, Feedar JA, editors. Wound healing: Alternative in management. Philadelphia (PA): FA Davis Company; 1990. p. 221-56. 
26. Gault WR, Gatens PF Jr. Use of low intensity direct current in management of ischemic skin ulcer. Phys Ther. 1976; 56(3):265-69. [PMID: 1083031]

27. Gray H, Williams PL, Bannister LH, Berry MN. Gray’s anatomy: The anatomical basis of medicine and surgery. New York (NY): Churchill Livingstone; 1995. p. 412, 417.
28. Majno G. The story of myofibroblasts. Am J Surg Pathol. 1979;3(6):535-42. [PMID: 534390]

Submitted for publication May 25, 2005. Accepted in revised form November 7, 2005. 